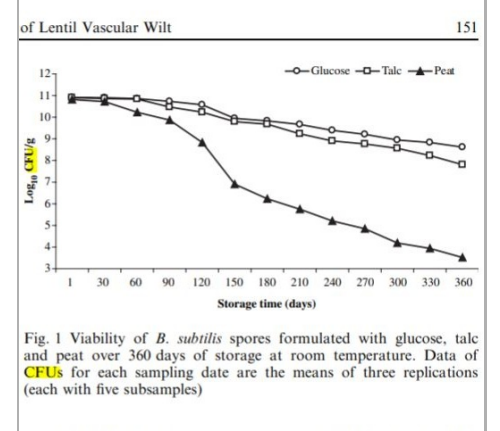

OCT 24, 2020

\section{open 2 ACCESs}

\section{DOI:}

dx.doi.org/10.17504/protocol s.io. bkrckv2 w

Protocol Citation: Andreea S 2020. Measuring the amuont of bacteria in a soil sample. protocols.io

https://dx.doi.org/10.17504/p rotocols.io.bkrckv2w

License: This is an open access protocol distributed under the terms of the Creative Commons Attribution License, which permits unrestricted use, distribution, and reproduction in any medium, provided the original author and source are credited

Protocol status: Other The protocol is developed based on literature and has not been tested yet.

Created: Sep 03, 2020

Last Modified: Oct 24, 2020

\section{(3) Measuring the amuont of bacteria in a soil sample}

Andreea $\mathrm{S}^{1}$

${ }^{1}$ University of Groningen

iGEM Groningen 2020

r.rajadhyaksha

\section{ABSTRACT}

Colony Forming Units (c.f.u) is a unit that is used in microbiology to estimate the number of viable bacteria or fungal cells in a sample. It also depends on their ability to multiply under controlled conditions. In the paper published by El-Hassan and Gowen, 2006, they analyzed various formulations of Bacillus subtilis by counting the $\mathrm{CFU}$ of $\mathrm{B}$. subtilis present in every formulated product.

\section{CITATION}

S. A. El-Hassan and S. R. Gowen (2006). Formulation and Delivery of the Bacterial Antagonist Bacillus subtilis for Management of Lentil Vascular Wilt Caused by Fusarium oxysporum f. sp. lentis. Journal of Phytopathology, Volume 154, Issue 3.

LINK

https://doi.org/10.1111/j.1439-0434.2006.01075.x

PROTOCOL integer ID:

41476

\title{
CFU determination
}

1 Colony Forming Units (CFU) can be determined by estimating the OD of spore suspension using a 
tube-reading spectrophotometer adjusted at 1.978 [corresponding to $8.5 \cdot 1010 \mathrm{CFU} / \mathrm{ml}$ ] at $600 \mathrm{~nm}$ absorbance wavelength

2 The formulation will be placed on sterile aluminum foil in pans and air-dried for $24: 00: 00$ with occasional stirring in a laminar airflow cabinet.

3 Dried formulations (35\% moisture content) of B. mycoides will be passed through a $250 \mu \mathrm{m}$ mesh sieve to attain the desired particle size.

4 Pack in sterilized polypropylene bags, seal and store at room temperature prior to use.

5 Count CFUs to estimate the number of viable propagules of B. mycoides using the standard dilution platin method described in step 6 .

\section{Standard dilution method}

6 Take three $\triangle 1 \mathrm{~g}$ aliquots of the dried powder and place in $\triangle 99 \mathrm{~mL}$ sterile PBST solution (this will include PBS + [M] $0.05 \%(\mathrm{v} / \mathrm{v})$ Tween 20). Stir magnetically at high speed for

(3) 00:15:00 . Now dilute this suspension with approximately and take $\triangle 0.2 \mathrm{~mL}$ of this suspension and plate on Nutrient Agar (NA) media. 